\title{
PENGARUH SIKAP PEDAGANG KAKI LIMA (PKL) TERHADAP IMPLEMENTASI PERATURAN DAERAH KOTA SAMARINDA NOMOR 19 TAHUN 2001 TENTANG PENGATURAN DAN PEMBINAAN PEDAGANG KAKI LIMA DALAM WILAYAH KOTAMADYA DAERAH TINGKAT II SAMARINDA (STUDI KASUS PADA PEDAGANG KAKI LIMA DI KAWASAN JL. PRAMUKA KOTA SAMARINDA).
}

\author{
Shorea Helminasari \\ Dosen Ilmu Administrasi Publik FISIP Universitas Widya Gama Mahakam Samarinda \\ e-mail: shorea@uwgm.ac.id
}

\begin{abstract}
Abstrak
Berdasarkan studi pendahuluan di kawasan Jl. Pramuka Kota Samarinda dengan sasaran utamanya adalah para Pedagang Kaki Lima (PKL), kenyataannya walaupun telah ada kebijakan yang mengatur tentang Pedagang Kaki Lima tersebut melalui Peraturan Daerah Nomor 19 Tahun 2001 Tentang Pengaturan dan Pembinaan Pedagang Kaki Lima belumlah terimplementasikan dengan baik. Sosialisasi kepada para PKL masih dianggap belum maksimal dan belum ada upaya dari pihak pemerintah untuk menyediakan sarana atau tempat untuk para PKL berdagang atau berjualan, sehingga menyebabkan para PKL tidak memperdulikan aturan yang ada. Tujuan dari penelitian ini adalah untuk mengetahui pengaruh sikap PKL di kawasan Jl. Pramuka Kota Samarinda Nomor 19 Tahun 2001 Tentang Pengaturan dan Pembinaan Pedagang Kaki Lima Kota Samarinda. Kawasan Jl. Pramuka Kota Samarinda berada di dua wilayah kelurahan, yaitu Kelurahan Gunung Kelua dan Kelurahan Sempaja Selatan. Metode yang digunakan dalam penelitian ini adalah metode penelitian kuantitatif karena data yang digunakan berupa angka-angka dan analisisnya menggunakan statistik.

Dalam hal ini diperlukan keseriusan pemerintah dalam mengajak masyarakat untuk menjalankan peraturan tersebut. Keberhasilan implementasi Peraturan Daerah tersebut tidak hanya tergantung pada aparatur pelaksanan tetapi juga memerlukan ketegasan sikap masyarakat terutama para PKL untuk tidak berjualan di tempat-tempat yang dilarang oleh pemerintah.
\end{abstract}

Kata Kunci: Implementasi Peraturan Daerah, Pengaturan dan Pembinaan Pedagang Kaki Lima, Sikap Masyarakat

\begin{abstract}
Based on preliminary study in Jl. Samarinda City scout with the main target is the street vendors (PKL), in fact although there has been a policy regulating the street traders through the Regional Regulation No. 19 of 2001 on the regulation and fostering of street vendors has not been implemented properly. Socialization to the street vendors is still considered not maximal and there has been no effort from the government to provide a means or place for street vendors to trade or sell, thus causing the street vendors do not care about the existing rules. The purpose of this study is to determine the influence of attitudes street vendors in the area Jl. Scouting of Samarinda City Number 19 Year 2001 About Arrangement and Guidance of Samarinda City Street Traders. Area Jl. Samarinda City scouts are located in two urban villages, Kelurahan Gunung Kelua and South Sempaja Village. The method used in this study is quantitative research methods because the data used in the form of numbers and analysis using statistics.
\end{abstract}


In this case the seriousness of the government is needed in inviting people to run the regulation. The success of the implementation of the Regional Regulation is not only dependent on the apparatus but also requires the assertiveness of public attitudes, especially the street vendors not to sell in places that are prohibited by the government.

Keywords: Implementation of Local Regulation, Arrangement and Guidance of Street Traders, Public Attitudes

\section{Pendahuluan}

Istilah "Kaki Lima" sudah lama dikenal di Indonesia. Istilah ini berasal dari zaman antara tahun 1811 sampai 1816, saat Napoleon menguasai Benua Eropa dan daerah Koloni Belanda di Asia berada dibawah kekuasaan administrasi Inggris. Saat itu Gubernur Jenderal di Indonesia, Sir Thomas Stamford Raffles menginstruksikan sistem lalu lintas di sebelah kiri di jalan-jalan raya sekaligus mengeluarkan aturan bahwa di tepitepi jalan harus dibuat trotoar untuk pejalan kaki yang tingginya harus $31 \mathrm{~cm}$, dan lebarnya sekitar $150 \mathrm{~cm}$ atau "Five Feet". Dari Perkataan "Five Feet" inilah maka para pedagang yang menjalankan usaha diatas trotoar mendapat julukan "kaki lima".

Kota Samarinda sebagai tempat terjadinya proses ekonomi, dimana merupakan pusat pertokoan dan terdapat juga pasar-pasar sehingga tidak heran jika di kota Samarinda terdapat banyak pedagang kaki lima. Keberadaan pedagang kaki lima dirasa sangat mengganggu karena merusak pemandangan kota, kondisi wilayah sekitar area perdagangan menjadi sangat tidak enak dipandang oleh mata dan lingkungan di daerah tersebut menjadi tidak bersih, belum lagi ditambah dengan semakin banyaknya pedagang kaki lima yang bermunculan sehingga menimbulkan kesan yang kumuh.

Untuk mengatur dan memberikan pembinaan pedagang kaki lima tidak lagi mengganggu ketertiban dan keindahan kota Samarinda, maka dibuat peraturan daerah, berdasarkan pada Peraturan Daerah Nomor 19 Tahun 2001 tentang Pengaturan dan Pembinaan terhadap Pedagang Kaki Lima, yang berbunyi (1) pengadaan, pemindahan dan penghapusan lokasi pedagang kaki lima ditetapkan oleh Walikota, (2) lokasi dan pengaturan tempat-tempat usaha pedagang kaki lima sebagaimana dimaksud ayat (1) ditunjuk dan ditetapkan oleh Walikota, (3) penunjukkan dan atau penetapan tempattempat usaha pedagang kaki lima sebagaimana dimaksud ayat (2) adalah lokasi milik dan atau yang dikuasai oleh Pemerintah Daerah atau pihak lain.

Berdasarkan studi pendahuluan di kawasan Jl. Pramuka Kota Samarinda yang berbatasan dengan Kecamatan Samarinda Utara dan Samarinda Ulu, disekitarnya banyak terdapat pedagang kaki lima yang menjajakan dagangannya tanpa mengindahkan aturan yang ada, padahal diketahui telah ada Peraturan Daerah Nomor 19 Tahun 2001 tentang Pengaturan dan Pembinaan Terhadap Pedagang Kaki Lima, yang seharusnya para pedagang kaki lima sudah tertata dengan rapi tanpa mengganggu aktivitas di sekitar daerah tersebut. Akan tetapi kenyataannya walaupun telah ada kebijakan yang mengatur pedagang kaki lima tersebut, dirasakan Peraturan Daerah Nomor 19 Tahun 2001 tentang Pengaturan dan Pembinaan Pedagang Kaki Lima belum terimplementasikan dengan baik, hal ini dibuktikan dengan adanya upaya penertiban dan pembinaan PKL oleh Pemerintah Kota Samarinda pada bulan Maret 2017. Mungkin saja sosialisasi kepada para pedagang kaki lima itu masih belum maksimal dan belum adanya sarana atau tempat untuk pedagang kaki lima itu berdagang, yang menyebabkan mereka tidak memperdulikan peraturan yang ada, kiranya pemerintah perlu menangani permasalahan pedagang kaki lima ini secara lebih optimal lagi.

Penertiban dan pembinaan terhadap pedagang kaki lima di kawasan Jl. Pramuka itu sebaiknya harus sering dilakukan agar para pedagang kaki lima di kawasan tersebut 
menyadari bahwa di kawasan itu bukanlah tempat untuk mereka berdagang. Selain kotor dan tidak rapi, kadang mereka juga bisa mengakibatkan kemacetan. Hal ini dikarenakan pedagang kaki lima menggunakan pinggiran jalan untuk menggelar dagangannya, padahal pinggiran jalan itu dibuat untuk para pejalan kaki. Dikarenakan dipakainya pinggiran jalan untuk berjualan, maka pejalan kaki menggunakan sebagian jalan raya untuk berjalan, hal inilah yang mengakibatkan kemacetan. Selain itu, hal lain yang menyebabkan kemacetan adalah akibat dari para pembeli yang mampir dan parkir kendaraan di badan jalan kawasan Jl. Pramuka, memang diperlukan kerja yang ekstra dari Pemerintah Kota Samarinda untuk menertibkan permasalahan seperti ini, namun diperlukan juga sikap kesadaran dari warga untuk saling menjaga agar sesuai dengan motto kota Samarinda yaitu "TEDUH, RAPI, INDAH, AMAN, dan NYAMAN (TEPIAN)". Sikap berkaitan dengan aspek sikap yang terdiri atas Komponen Kognitif (Perseptual), Komponen Afektif (Emosional), dan Komponen Konatif (Perilaku). Ketiga komponen tersebut wajib dimiliki oleh masyarakat agar pengelolaan dan penertiban terhadap pedagang kaki lima di Samarinda khususnya di kawasan Jl, Pramuka dapat berjalan maksimal.

\subsection{Permasalahan}

Adapun yang menjadi permasalahan dalam penelitian ini yakni apa pengaruh sikap pedagang kaki lima terhadap implementasi Peraturan Daerah Kota Samarinda Nomor 19 Tahun 2001 Tentang Pengaturan dan Pembinaan Pedagang Kaki Lima Kota Samarinda, dan sejauh mana keberhasilan Peraturan Daerah Kota Samarinda Nomor 19 Tahun 2001 tentang Pengaturan dan Pembinaan Pedagang Kaki Lima di kawasan Jl. Pramuka Kota Samarinda?

\subsection{Tujuan}

Adapun yang menjadi tujuan dalam penelitian ini untuk mengetahui hubungan variabel antara sikap pedagang kaki lima terhadap implementasi Peraturan Daerah Kota Samarinda Nomor 19 Tahun 2001 Tentang Pengaturan dan Pembinaan Pedagang Kaki Lima Kota Samarinda, serta mengetahui sejauh mana keberhasilan Peraturan Daerah Kota Samarinda Nomor 19 Tahun 2001 tentang Pengaturan dan Pembinaan Pedagang Kaki Lima di kawasan Jl. Pramuka Kota Samarinda.

\section{Kerangka Teori}

\subsection{Sikap}

Menurut Baron dan Byrne (dalam Walgito, 2003:126) berpendapat bahwa "sikap sebagai ketahanan yang relatif terhadap klaster perasaan, keyakinan, dan kecenderungan perilaku diarahkan kepada orang-orang tertentu, ide, objek, atau kelompok".

Menurut Rokeach (dalam Walgito, 2003:126) mengemukakan bahwa "sikap telah terkandung komponen kognitif dan juga komponen konatif, yaitu sikap merupakan predisposing untuk merespons, untuk berperilaku. Ini berarti bahwa sikap berkaitan dengan perilaku, sikap merupakan predispose untuk berbuat atau berperilaku".

Menurut Myers (dalam Walgito, 2003:127) berpendapat bahwa "sikap telah mengandung komponen kognitif (Beliefs), komponen afektif (Feelings), dan komponen konatif (Behavior Tendencies).

Menurut Walgito (2003:127) berpendapat bahwa "sikap merupakan organisasi pendapat, keyakinan seseorang mengenai objek atau situasi yang relative ajeg, yang disertai adanya perasaan tertentu, dalam memberikan dasar kepada orang tersebut untuk membuat respon atau berperilaku dalam cara tertentu yang dipilihnya".

Menurut Gerungan (dalam Walgito, 2003:127) berpendapat bahwa "pengertian sikap itu dapat kita terjemahkan dengan kata sikap terhadap objek tertentu, yang dapat 
merupakan sikap pandangan atau sikap perasaan, tetapi sikap mana disertai oleh kecenderungan bertindak sesuai dengan sikap terhadap objek tadi. Jadi sikap itu lebih dapat diterjemahkan sebagai sikap dan kesedihan bereaksi terhadap sesuatu hal".

Menurut Katz (dalam Walgito, 2003:128) mengatakan sikap itu mempunyai 4 (empat) fungsi, yaitu :

a. Fungsi Instrumental, atau fungsi penyesuaian, atau fungsi manfaat.

b. Fungsi Pertahanan Ego.

c. Fungsi Ekspresi Nilai.

d. Fungsi Pengetahuan.

Menurut Walgito (2003:130) mengatakan sikap itu dipengaruhi oleh beberapa faktor penting, yaitu :

a. Faktor Fisiologis.

b. Faktor Pengalaman Langsung Terhadap Objek Sikap.

c. Faktor Kerangka Acuan.

d. Faktor Komunikasi Sosial.

Dalam hal ciri-ciri sikap, Walgito (2003:131-132) menjelaskan sebagai berikut:

a. Sikap itu tidak dibawa sejak lahir.

b. Sikap itu selalu berhubungan dengan objek sikap.

c. Sikap dapat tertuju pada suatu objek saja, tetapi juga dapat tertuju pada sekumpulan objek-objek.

d. Sikap itu dapat berlangsung lama atau sebentar.

e. Sikap itu mengandung faktor perasaan dan motivasi.

Ini berarti bahwa sikap terhadap sesuatu objek tertentu akan selalu diikuti oleh perasaan tertentu yang dapat bersifat positif (yang menyenangkan) tetapi juga dapat bersifat negatif (yang tidak menyenangkan) terhadap objek tersebut. Disamping itu sikap juga mengandung motivasi, ini berarti bahwa sikap itu mempunyai daya dorong bagi individu untuk berperilaku secara tertentu terhadap objek yang dihadapinya.

\subsection{Kebijakan}

Menurut Mustopadidjaja (2007), "Kebijakan adalah keputusan suatu organisasi yang dimaksudkan untuk mengatasi permasalahan tertentu sebagai keputusan atau untuk mencapai tujuan tertentu, berisikan ketentuan-ketentuan yang dapat dijadikan pedoman perilaku dalam pengambilan keputusan lebih lanjut yang harus dilakukan baik kelompok sasaran ataupun (unit) organisasi pelaksana kebijakan, penerapan atau pelaksanaan dari suatu kebijakan yang telah ditetapkan baik dalam hubungan (unit) organisasi pelaksana maupun dengan kelompok sasaran yang dimaksudkan".

Menurut Carter V. Good (1959) memberikan pengertian kebijakan pendidikan (educational policy) dalam buku karya Ali Imron yang berjudul Kebijaksanaan Pendidikan di Indonesia (2012), "Kebijakan adalah sebuah pertimbangan yang didasarkan atas suatu nilai dan beberapa penilaian terhadap faktor-faktor yang bersifat situasional, untuk mengoperasikan perencanaan yang bersifat umum dan memberikan bimbingan dalam pengambilan keputusan demi tercapainya tujuan".

Menurut Carl J. Federick sebagaimana dikutip Agustino (2008:7) mendefinisikan kebijakan sebagai serangkaian tindakan/kegiatan yang diusulkan seseorang, kelompok 
atau pemerintah dalam suatu lingkungan tertentu dimana terdapat hambatan-hambatan (kesulitan-kesulitan) dan kesempatan terhadap pelaksanaan usulan kebijaksanaan tersebut dalam rangka mencapai tujuan tertentu.

Solichin Abdul Wahab mengemukakan bahwa istilah kebijakan sendiri masih terjadi silang pendapat dan merupakan ajang perdebatan para ahli. Maka untuk memahami istilah kebijakan, Solichin Abdul Wahab (2008: 40-50) memberikan beberapa pedoman sebagai berikut :

a. Kebijakan harus dibedakan dari keputusan

b. Kebijakan tidak serta merta dapat dibedakan dari administrasi

c. Kebijakan mencakup perilaku dan harapan-harapan

d. Kebijakan mencakup ketiadaan tindakan ataupun adanya tindakan

e. Kebijakan biasanya mencakup hasil akhir yang akan dicapai

f. Setiap kebijakan memiliki tujuan atau sasaran tertentu baik eksplisit maupun implicit

g. Kebijakan muncul dari suatu proses yang berlangsung sepanjang waktu

h. Kebijakan meliputi hubungan-hubungan yang bersifat antar organisasi dan yang bersifat intra organisasi

i. Kebijakan itu dirumuskan atau didefinisikan secara subyektif.

Berdasarkan pendapat berbagai ahli tersebut di atas maka dapat disimpulkan bahwa kebijakan adalah tindakan-tindakan atau kegiatan yang sengaja dilakukan atau tidak dilakukan oleh seseorang, suatu kelompok atau pemerintah yang di dalamnya terdapat unsur keputusan berupa upaya pemilihan diantara berbagai alternatif yang ada guna mencapai maksud dan tujuan tertentu.

\subsection{Kebijakan Publik}

Lingkup dari studi kebijakan publik sangat luas karena mencakup berbagai bidang dan sektor seperti ekonomi, politik, sosial, budaya, hukum, dan sebagainya. Disamping itu dilihat dari hirarkirnya kebijakan publik dapat bersifat nasional, regional maupun lokal seperti Undang-Undang, Peraturan Pemerintah, Peraturan Presiden, Peraturan Menteri, Peraturan Pemerintah Daerah/Provinsi, Keputusan Gubernur, Peraturan Daerah Kabupaten/Kota, dan Keputusan Bupati/Walikota.

Secara terminologi pengertian kebijakan publik (public policy) itu ternyata banyak sekali, tergantung dari sudut mana kita mengartikannya. Easton memberikan definisi kebijakan publik sebagai the authoritative allocation of values for the whole society atau sebagai pengalokasian nilai-nilai secara paksa kepada seluruh anggota masyarakat. Laswell dan Kaplan juga mengartikan kebijakan publik sebagai a projected program of goal, value, and practice atau sesuatu program pencapaian tujuan, nilai-nilai dalam praktek-praktek yang terarah.

Menurut Werf (2004) yang dimaksud dengan kebijakan publik mempunyai pengertian baku, yaitu suatu keputusan yang dibuat secara sistematik oleh pemerintah dengan maksud dan tujuan tertentu yang menyangkut kepentingan umum sesuai dengan sistem administrasi negara Republik Indonesia. 
Menurut Dunn yang dikutip Syafiie (2006:106) kebijakan publik adalah suatu rangkaian pilihan-pilihan yang saling berhubungan yang dibuat oleh lembaga atau pejabat pemerintah pada bidang-bidang yang menyangkut tugas pemerintah.

Thomas R Dye sebagaimana dikutip Islamy (2009: 19) mendefinisikan kebijakan publik sebagai " is whatever government choose to do or not to do" ( apapaun yang dipilih pemerintah untuk dilakukan atau untuk tidak dilakukan). Definisi ini menekankan bahwa kebijakan publik adalah mengenai perwujudan "tindakan" dan bukan merupakan pernyataan keinginan pemerintah atau pejabat publik semata. Di samping itu pilihan pemerintah untuk tidak melakukan sesuatu juga merupakan kebijakan publik karena mempunyai pengaruh (dampak yang sama dengan pilihan pemerintah untuk melakukan sesuatu).

Berdasarkan pendapat berbagai ahli tersebut dapat disimpulkan bahwa kebijakan publik adalah serangkaian tindakan yang dilakukan atau tidak dilakukan oleh pemerintah yang berorientasi pada tujuan tertentu guna memecahkan masalah-masalah publik atau demi kepentingan publik. Kebijakan untuk melakukan sesuatu biasanya tertuang dalam ketentuanketentuan atau peraturan perundang-undangan yang dibuat pemerintah sehingga memiliki sifat yang mengikat dan memaksa.

\subsection{Peraturan Daerah}

Salah satu kewenangan yang sangat penting dari suatu daerah yang mengatur dan mengurus rumah tangganya sendiri ialah kewenangan untuk menetapkan peraturan daerah.

Sebagaimana didefinisikan oleh Undang-Undang Nomor 10 Tahun 2004 tentang Pembentukan Peraturan Daerah adalah peraturan perundang-undangan yang dibentuk oleh Dewan Perwakilan Rakyat Daerah (DPRD) dengan persetujuan bersama kepala daerah. Keberadaan Perda dalam penyelenggaraan pemerintahan daerah tidak lepas dari prinsip desentralisasi yang dilakukan oleh pemerintah pusat. Materi muatan perda juga terdapat dalam 136 ayat 6 sampai dengan ayat 8 Undang-Undang Nomor 32 Tahun 2004 tentang Pemerintahan Daerah, yaitu ayat 6 disebutkan Perda dibentuk dalam rangka penyelenggaraan otonomi daerah Provinsi/Kabupaten/Kota dan tugas pembantuan.

Disamping dikenal adanya istilah peraturan, dikenal juga istilah perundangundangan, untuk itu M. Solly Lubis memberikan pengertian perundang-undangan. Pengertian perundang-undangan ialah proses pembuatan peraturan Negara. Dengan dengan kata lain tata cara mulai perencanaan (rancangan), pembahasan, pengesahan atau penetapan ahirnya pengundangan peraturan yang bersangkutan.

K. Wantjik Saleh memberikan pengertian yang berbeda tentang perundangundangan, perundang-undangan adalah "Undang-undang dalam arti luas" atau yang dalam ilmu hukum disebut "Undang-undang dalam arti materiil" yaitu segala peraturan yang tertulis yang di buat oleh penguasa (baik pusat maupun daerah) yang mengikat dan berlaku umum, termasuk dalamnya undang-undang darurat, peraturan pemerintah pemerintah penggati undang-undang, peraturan pemerintah, penetapan presiden, peraturan profinsi, peraturan kotamadya, dan lain-lain.

\subsection{Pedagang Kaki Lima}

Menurut Lili N. Schock dalam bukunya menyebutkan istilah "kaki lima" sudah lama dikenal di tepi jalan. Istilah ini berasal dari zaman antara tahun 1811 sampai 1816, 
saat Napoleon menguasai Benua Eropa dan daerah Koloni Belanda di Asia berada dibawah kekuasaan administrasi Inggris. Saat itu Gubernur Jenderal di Indonesia, Sir Thomas Stamford Raffles menginstruksikan sistem lalu lintas di sebelah kiri di jalan-jalan raya sekaligus mengeluarkan aturan bahwa di tepi-tepi jalan harus dibuat trotoar untuk pejalan kaki yang tingginya harus $31 \mathrm{~cm}$, dan lebarnya sekitar $150 \mathrm{~cm}$ atau "Five Feet". Dari Perkataan "Five Feet" inilah maka para pedagang yang menjalankan usaha diatas trotoar mendapat julukan "kaki lima".

Pemahaman pedagang kaki lima saat ini telah berkembang dan dilihat dari berbagai sudut pandang. Dalam pandangan pemerintah disebutkan bahwa pedagang kaki lima adalah pelaku usaha yang melakukan usaha perdagangan dengan menggunakan sarana usaha bergerak maupun tidak bergerak, menggunakan prasarana kota, fasilitas sosial, fasilitas umum, lahan dan bangunan milik pemerintah dan/atau swasta yang bersifat sementara/tidak menetap (Permendagri Nomor 41/2012 Pasal 1).

Menurut An-nat (2001:30), "Pedagang kaki lima adalah suatu usaha yang memerlukan modal relatif sedikit, berusaha dalam bidang produksi dan penjualan untuk memenuhi kebutuhan kelompok konsumen tertentu". Usahanya dilaksanakan pada tempat-tempat yang dianggap strategis dalam lingkungan yang informal.

Sebagaimana dikemukakan oleh Wignjosoebroto (2008:91), bahwa "Para pedagang kaki lima yang menjajakan barang dagangannya di berbagai sudut kota sesungguhnya adalah kelompok masyarakat yang tergolong marginal, dan tidak berdaya". Dikatakan margianal sebab mereka rata-rata tersisih dari arus kehidupan kota dan bahkan terkurung oleh kemajuan kota itu sendiri. Sedangkan dikatakan tidak berdaya karena mereka biasanya tidak terjangkau dan tidak terlindungi oleh hukum, posisi bargaining (tawar menawar) lemah, dan sering kali menjadi objek penertiban dan penataan kota yang tak jarang bersifat represif.

Oleh sebab itu, pedagang kaki lima dapat dianggap sebagai kegiatan ekonomi masyarakat bawah. Memang secara defacto pedagang kaki lima adalah sebagai pelaku ekonomi di pinggiran jalan. Pedagang kaki lima dalam melakukan aktivitasnya dimana barang dagangannya diangkut dengan gerobak dorong, bersifat sementara, dengan alas tikar dan/atau tanpa meja serta memakai atau tanpa tempat gantungan untuk memajang barang-barang jualannya, dan/atau tanpa tenda, dan kebanyakan jarak tempat usaha antara mereka tidak dibatasi oleh batas-batas yang jelas. Para pedagang kaki lima ini tidak mempunyai kepastian hak atas tempat usahanya.

Penyebab menjamurnya pedagang kaki lima seiring dengan adanya krisis moneter yang sudah begitu akut, adalah ciri-ciri yang khas dari sektor informal, yaitu :

a. Mudah dimasuki

b. Fleksibel (waktu dan tempat beroperasinya)

c. Bergantung pada sumber daya lokal

d. Skala operasinya yang kecil

\section{Metode}

Berdasarkan permasalahan dan tujuan penelitian, maka peneliti menggunakan skala Likert yang berjenjang $3(1,2,3)$ dalam menggunakan nilai atau skor. Untuk keperluan analisis kuantitatif. Untuk menganalisis data yang dipergunakan atau yang dihasilkan dalam variabel sikap pedagang kaki lima yaitu menggunakan alat analisis data distribusi frekuensi Frekuensi tersebut juga dapat dilihat penyebaran presentasenya, yang oleh 
kebanyakan orang dikenal dengan frekuensi relatif. Untuk menghitung besaran presentase dari frekuensi tersebut, dapat digunakan rumus :

$$
\begin{aligned}
& N=\frac{f x}{N} \times 100 \% \\
& \text { Keterangan : } \\
& \mathrm{N} \quad=\text { Jumlah Kejadian } \\
& F x=\quad \text { Frekuensi Individu }
\end{aligned}
$$

Teknik pengumpulan data pada penelitian ini dilakukan kepada populasi sebesar 50 (lima puluh) PKL, dan pengambilan sampel menggunakan teknik Simple Random Sampling.

\section{Fokus}

Penelitian ini difokuskan pada pengukuran variabel sikap pedagang kaki lima meliputi :

a. Kognitif (Perseptual)

Pandangan dan pengetahuan pedagang kaki lima terhadap implementasi Peraturan Daerah Kota Samarinda Nomor 19 Tahun 2001 tentang Pengaturan dan Pembinaan PKL.

b. Afektif (Emosional)

Perasaan senang atau tidak senang terhadap penerapan kebijakan publik melalui implementasi Peraturan Daerah Kota Samarinda Nomor 19 Tahun 2001 tentang Pengaturan dan Pembinaan PKL.

c. Konatif (Perilaku)

Sikap atau perilaku PKL dalam hal ketertiban dan ketepatan berjualan di sepanjang jalan Pramuka Kota Samarinda.

\section{Hasil}

1) Perhitungan data yang telah diperoleh dari indikator kognitif (perseptual) dengan diukur dari item-item pertanyaan per indikator kognitif, maka perhitungan rekapitulasi untuk indikator kognitif dapat diketahui bahwa para PKL di sepanjang jalan Pramuka Kota Samarinda tidak mengetahui adanya Peraturan Daerah Kota Samarinda Nomor 19 Tahun 2001 Tentang Pengaturan dan Pembinaan PKL, dimana sebagian responden berpendapat bahwa responden tidak mengetahui tentang kebijakan pengaturan dan pembinaan PKL.

2) Perhitungan data yang telah diperoleh dari indikator afektif (emosional) dengan diukur dari item-item pertanyaan per indikator afektif, maka perhitungan rekapitulasi untuk indikator afektif dapat diketahui bahwa para PKL di sepanjang jalan Pramuka Kota Samarinda merasa terganggu dengan adanya penertiban PKL dan penerapan Peraturan Daerah Kota Samarinda Nomor 19 Tahun 2001 Tentang Pengaturan dan Pembinaan PKL, dimana sebagian responden berpendapat bahwa responden merasa terganggu dengan adanya penertiban PKL.

3) Perhitungan data yang telah diperoleh dari indikator konatif (perilaku) dengan diukur dari item-item pertanyaan per indikator konatif maka perhitungan rekapitulasi untuk indikator konatif dapat diketahui bahwa para PKL di sepanjang jalan Pramuka Kota Samarinda berperilaku tidak sesuai dengan aturan yang ditetapkan oleh pemerintah melalui kebijakan daerah Peraturan Daerah Kota 
Samarinda Nomor 19 Tahun 2001 Tentang Pengaturan dan Pembinaan PKL, dimana masih ada PKL yang tetap berjualan diatas trotoar di sepanjang jalan Pramuka Kota Samarinda.

\section{Daftar Pustaka}

Abdul Wahab, Solichin. 2008. Analisis Kebijakan Dari Formulasi Ke Implementasi Kebijaksanaan Negara. Edisi Kedua. Jakarta: PT. Bumi Aksara.

Agustino, Leo. 2008. Dasar-dasar Kebijakan Publik. Bandung : Alfabeta.

AG, Subarsono. 2010. Analisis Kebijakan Publik Konsep Teori dan Aplikasi. Yogyakarta Pustaka Pelajar.

AR, Mustopadidjaja. 2007. Manajemen Proses Kebijakan Publik (Formulasi, Implementasi Dan Evaluasi Kinerja). LAN RI Jakarta: Duta Pertiwi Foundation.

Arikunto, Suharsimi.(2002). Prosedur Penelitian Kebijakan Negara. Jakarta Rineka Cipta

Arikunto, Suharsimi.(2010). Prosedur Penelitian, Suatu Pendekatan praktik. Jakarta : Asdi Mahasatya.

Azwar S. 2009. Sikap Manusia (Edisi Revisi). Yogyakarta : Pustaka pelajar.

Damsar. 2001. Sosiologi Ekonomi. Bielefeld: PT Raja Grafindo Persada.

Dwiyanto, Indiahono. 2009. Kebijakan Publik Berbasis Dynamic Policy Analisys. Yogyakarta: Gava Media.

Effendi, Sofyan, 2001, Implementasi Kebijakan Publik, Gadjah Mada University Press: Yogyakarta.

Gaffar, Afan. 2009. Politik Indonesia: Transisi Menuju Demokrasi. Yogyakarta: Pustaka Pelajar.

HR, Ridwan. 2006. Hukum Administrasi Negara. Jakarta : PT Raja Grafindo.

Imron, Ali. 2012. Kebijaksanaan Pendidikan di Indonesia: Proses, Produk dan Masa Depanny. Bandung: Bumi Aksara.

Islamy, M. Irfan. 2009. Prinsip-prinsip Perumusan Kebijaksanaan Negara. Jakarta: Bumi Aksara.

Inu Kencana Syafiie. 2006. Ilmu Administrasi Publik. Edisi Revisi. Jakarta: Rineka Cipta.

Ivancevich, John, M, dkk. 2008. Perilaku dan Manajemen Organisasi, jilid 1 dan 2 Jakarta : Erlangga.

Kurniadi, Tri dan Tangkilisan, Hesel Nogi S. 2010, Ketertiban Umum dan Pedagang Kali Lima Di DKI Jakarta. Yogyakarta: YPAPI

Laswell, Harold D. Kaplan, Abraham. 1970. Power and Society, New Haven: Yale University Press.

Lubis, M. Solly. 1979. Pembahasan Undang-undang Dasar 1945, Alumni, Bandung.

Martono, Lydia Harlina. 2006. Belajar Hidup Bertanggung Jawab, Menangkal Narkoba dan Kekerasan. Jakarta: Balai Pustaka.

Mathis, dan Jackson, 2002. Manajemen Sumber Daya Manusia, Edisi pertama, Cetakan Pertama, Yogyakarta : Salemba Empat

Mathis, Robert. L dan Jackson, Jhon.H. 2009. Human Resource Management. Jakarta : Salemba Empat

Mardika Alam, Suluh. Implementasi Kebijakan Penataan pedagang Kali Lima Di Kabupaten Sumenep. Jurnal Pelopor Pendidikan. Vol. 8. No.1. Bulan Januari Tahun 2016.

Noer Effendi (1985) Definisi Pedagang Kaki Lima. Jakarta : Ui Press.

Nugroho, Riant. 2014. Public Policy. Jakarta: PT. Elex Media Komputindo.

Pasolong, Harbani. 2010. Teori Administrasi Publik. Bandung: Alfabeta 
Pasolong, Harbani. 2012. Metode Penelitian Administrasi Publik. Bandung: Alfabeta Peraturan Menteri Dalam Negeri Nomor 41 Tahun 2012 Tentang Pedoman Penataan Dan Pemberdayaan Pedagang Kaki Lima.

Poerwadarminta W.J.S. 1976. Kamus Umum Bahasa Indonesia. PN Balai Pustaka, Jakarta.

Ramadani, Agus. Pengaturan Dan Pembinaan Pedagang Kali Lima Dalam Wilayah Kotamadya Samarinda. E-Journal Ilmu Pemerintahan FISIP UNMUL.Vol.5. No. 1. Tahun 2017.

Saleh, K. Wantjik. 1982. Hukum Perkawinan Indonesia, Jakarta: Ghalia Indonesia.

Sethurahman (2004) Istilah Pedagang Kaki Lima : Airlangga Univercity Press.

Sugiyono, 2009, Metode Penelitian Kuantitatif, Kualitatif dan R\&D, Bandung : Alfabeta

Suandi, I Wayan. Eksistensi Kebijakan Publik dan Hukum Dalam Penyelenggaraan Pemerintahan Daerah. Jurnal Ilmiah Fakultas Ilmu Sosial dan Ilmu Politik. Vol. 1. No. 1 Tahun 2010

Syaukani, dkk. 2003. Otonomi Daerah dalam Negara Kesatuan. Yogyakarta: Pustaka Pelajar.

Tangkilisan, Hesel Nogi. 2003. Kebijakan Publik Yang Membumi. Yogyakarta: Lukman Offset YPAPI.

Undang-Undang Nomor 10 Tahun 2004 tentang Pembentukan Peraturan Daerah.

Undang-Undang Nomor 32 Tahun 2004 tentang Pemerintahan Daerah.

Usman, Nurdin. 2002. Konteks Implementasi Berbasis Kurikulum. Jakarta:PT.

Raja Grafindo Persada.

Walgito, Bimo. 2003. Pengantar Psikologi Umum. Yogyakarta: Andi.

Winarno, Budi. 2007. Kebijakan Publik Teori dan Proses. Jakarta: Media Pressindo.

Wirosardjono (1998) Pengertian Umum Pedagang Kaki Lima : Bumi Aksara Jakarta. 